\title{
[7]
}

\section{The Question of Age}

Discriminations based on age have been among the least controversial of legal distinctions. Where a line should be drawn-at eighteen or twenty-one for voting, at sixty-five or seventy for retirement-has often been a hot issue, but the notion that a line should be drawn somewhere has rarely been troublesome. Most of us have accepted the idea that young citizens may be forced to do things adults need not do, such as go to school, or forbidden to do things adults may do, such as drinking or driving. Similarly, there is little protest when older people are forced to take drivers' tests more frequently than others. In I980 many Americans were uncomfortable with the prospect of a seventy-year-old president, as, twenty years before, they were uneasy about one in his early forties. We have seen nothing arbitrary or unreasonable about such distinctions, but have tended to view them as recognitions of significant differences in human abilities. That, of course, is just how legal distinctions based on sex were once regarded, and that opinion has changed. One purpose of this chapter is to ask whether similar changes are needed in our thinking about age.

In many respects, age differs from all other traits on which legal classifications are based. Although, like race and sex, it is beyond individual control, it does change. What is fixed is the rate of that change. Another feature of age discrimination is that any line drawn is to some extent arbitrary and artificial, even if the states of life it demarcates are real. There are evident differences, for example, between infancy and childhood, adolescence and young adulthood, middle age and old age, but there is no exact age at which one stage ends and another begins. Eighteen is the voting age because we have to put it some- 


\section{Equality under the Constitution}

where, not because there is any magical difference between seventeen and eighteen. A final difference between age and most bases for discrimination is that it is not easy to substitute for the neutral term a group that is the usual target, as "blacks" can be exchanged with "race discrimination" or "women" for "sex discrimination." Age-based distinctions usually reach either the young or the old, but they can single out people who are not classifiable as either. For example, fifty is not commonly regarded as the beginning of old age, but that was where the line was drawn in Murgia.

Because of this imprecision, the law of age discrimination may seem to be too vast and unwieldy a subject for one chapter. After all, youth and age are antonyms, not synonyms. On the face of it, there seems to be more difference than similarity between, say, laws that make minors subject to parental control and laws that oblige people over seventy to take drivers' tests more often than others do.

But suppose we compare, instead, compulsory schooling to compulsory retirement. What do they have in common? Both policies set aside a place where the young or old do or do not belong, and do they not both imply that young and old should be segregated from the mainstream of society? Do such policies reflect equal respect and concern for the people excluded? Certainly we do not send people under sixteen to school for the same reasons that we force people to retire at fifty, or sixty-five, or seventy. But anyone who wishes to argue, as I do, that compulsory schooling is constitutional and compulsory retirement unconstitutional must deal with the similarities as well as the differences.

\section{Paternalism,' Patriotism, and Patriarchy}

Chapter 5 discussed the two major retirement cases, Murgia and Bradley. There I criticized Bradley, in particular, for the assumption that the interests of the retirees could be sacrificed to those of the younger Foreign Service officers. I was less concerned there with attitudes toward the aging than with the results of applying the rigid equalprotection model. Now I shall take up the specific problem, and begin by suggesting that the treatment of the aging has much in common with the treatment of the young.

At first glance, it does not seem that way. In general, with the exception of a few specific laws, older people have the legal status of all adult citizens. Children have a special, restricted status that pervades every aspect of their lives. Legally, a minor child is an "infant." The 
word comes from the Latin infans, which literally means "not having the facility of speech"; it refers, overinclusively, to children under the age of seven. The common English meaning of the word is "baby" or "young child," but the law, again overinclusively, so labels all minors of whatever age.

Infants are presumed to be incompetent. Absent contrary evidence, their parents are presumed to act in their best interests. Similar assumptions are made about schools, where attendance is compulsory. Whether or not children themselves are ever consulted about their interests depends on the particular laws of particular states; there is no requirement that they must be. The cases I shall examine reflect both the assumption expressed by the word "infant," that minors are incompetent, and the derivative assumption that the adults closest to minors act in their best interests. That the cases in question reflect these assumptions is odd, for they contain much evidence against both of them.

In a case that actually enlarged the rights of juveniles, the Supreme Court described the general situation like this: "A child, unlike an adult, has a right 'not to liberty but to custody.' He can be made to attorn to his parents, to go to school, etc. If his parents default in effectively performing their custodial functions-that is, if the child is 'delinquent' - the state may intervene. In doing so, it does not deprive the child of any rights, for he has none." ${ }^{1}$ No rights, but many duties. Children "are expected to be good.... Perhaps the most important and least appreciated norm governing the lives of young people is that they are in every aspect of their presence, demeanor, and appearance accountable. Unlike adults, who can hold each other to account only on the basis of special entitlements and only to a limited extent, young people must answer fully to their parents." 2 And when parents do not hold their children to account, the school and the state step in, in force.

The case of Walter Polovchak illustrates this situation. Early in 1980, when Walter was twelve, his family emigrated from the Soviet Union and settled in Chicago's Ukranian community. That summer, the parents decided to return home. Walter wanted to stay, and ran away to relatives in the community. The Immigration and Naturalization Service granted him asylum, and a federal judge ruled that his parents could not take him back to the Ukraine. The parents took their case

${ }^{1}$ Re Gault, 387 U.S. I, 17 (1967).

${ }^{2}$ Egon Bittner, "Policing Juveniles: The Social Context of Common Practice," in Margaret K. Rosenheim, ed., Pursuing Justice for the Child (Chicago: University of Chicago Press, 1976), pp. 73-74. Emphasis in the original. 
to the Illinois courts. In December I98I a state appeals court awarded custody of Walter to his parents, but neither state nor federal authorities made any effort to return him. The parents have since returned to the Ukraine, and the case goes on-as Walter approaches adulthood. ${ }^{3}$

Not surprisingly, the case has had widespread publicity. After all, it presents a conflict between two cherished American ideals: patriotism and family life. Typically, it has been the familial knee that has jerked. Opinion has tended to side with the parents. So do the American Civil Liberties Union, which took their case; the New York Times; and the well-known liberal columnist Ellen Goodman, who has criticized court decisions upholding parents' rights to institutionalize their children. She wrote:

If it happened to an American family, it would be an outrage.... The fact is that we have given much more weight to this Ukranian boy's testimony than to any American boy of the same age.

... Is he, like so many of his age, testing the limits, tasting his first tidbits of rebellion? Or can he be mature enough to choose political freedom above family?

... Our laws assume [except in rare instances] that the parent is the best judge of the state of mind, the needs and the future, of the child. Whether we approve or not, we do not interfere unless they have been proven unfit. ${ }^{4}$

Walter, of course, is in no sense independent. Without his extended family, he would have no real choices. No more than the society Walter left does this one permit a twelve-year-old to be autonomous. Walter's choices-and they have not been his, but the courts'-are between being subject to his parents in the Ukraine and being subject to a guardian in the United States. Walter could not earn a living wage; even if he could, or if he had an independent income, he would not be allowed to control the money; and his ability to earn is limited by the fact that he must go to school. Without an income, Walter could not buy necessities.

Twelve-year-olds can do many of the things for which adults are

3 "Boy Seeks Asylum, Defying Russian-Born Parents," Washington Post, July 21, 1980, p. A9. See also New York Times, February 20, 198 I, p. 8; June 4, I98I, II, p. I4; August 4, I98I, p. 8; August 6, I98I, p. Iо; August 13, I98I, p. I3; August 29, I98 I, p. 8; October 22, 198I, p. 19; November 26, 1981, p. 16; December 31, 198I, pp. I, B6; February 16,1982 , p. I2.

4"The Parent Is the Best Judge," Washington Post, August 9, 1980, p. Ar9. But see "Checks on Parental Power," in Goodman, At Large (New York: Summit Books, I98 I), pp. I 70-7I. 
paid. They can also keep themselves alive; they can buy and prepare food, clothe themselves, and get housing. But they are not allowed to earn a living wage, and therefore to get what they need. Moreover, most of the skills that children must have in order to become autonomous adults, such as reading and writing, are not taught them until long after they are capable of learning them. A twelve-year-old's dependence is as much the result of social practices as it is of personal limitations.

Is a child Walter's age "mature enough" to be independent? It is not clear why this should be the first question; why not begin instead by asking about the consequences to the child of the decision? Often what adults mean by children's "maturity" is obedience, tractability, and agreement with them. Walter, of course, has passed that test, since he agrees with most of us about where he would rather live. Sarcasm aside, Walter did give some reasons for his choice, and at first glance they cast doubt on his maturity. He spoke of his fondness for American ice cream, bicycles, "lots of food," and the fact that "you can buy many things here." 5 But what can we expect? Would it have been more mature of him to speak in clichés about American democracy? After all, children neither vote nor hold office; and, as aliens, neither could Walter's parents. Ice cream and bicycles reflect the limited range of choices available to a child, and the limited resources he commands. Expert opinions differ as to what children can do, and how mature they are, at what age, but when society denies children the power to do many of these things, the ability is beside the point.

However limited Walter's choices, his attempts to make them have disturbed many Americans. Our faith in the family, our belief that Mother and Father know best, are so great that parents get support even when few of us would agree with their decisions. The courts, too, may yet side with the parents. Few people seem to remember that only eight years before Walter Polovchak ran away from home, a similar case in Chicago, involving an even younger child, was decided in favor of the parents, and the result was tragic. Six-year-old Johnny Lindquist did not want to live with his parents, either. He had been placed in a foster home after his parents declared they could not support him. When they wanted him back, Johnny told a caseworker that he was afraid of his father and wanted to stay with his foster parents. But he was returned home; his father beat him; and in September 1972, after weeks in a coma, he died.

Of course, it would be unfair to compare the Polovchaks with the

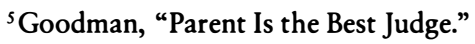




\section{Equality under the Constitution}

Lindquists. What the two cases share is not a truth about parents, but a truth about opinion and a truth about children. Time wrote of the Lindquist case: "As a result, an Illinois Senate Committee has been holding hearings on whether to change child-care laws to resemble those of California, where due weight is given to the child's own wishes about custody if he is of sufficient age and capacity to reason."' John Holt commented on this article:

... had such a law been on the books, I doubt that it would have made the slightest difference in the case of Johnny Lindquist or others like him. In the United States today what official body, what group of professional helpers and protectors of children, would agree that a six-year-old was "of sufficient age and capacity to reason"? And yet that is exactly the point of the story, and a point that Time magazine wholly missed. In this matter it was Johnny who was right. His judgment was more accurate and his reasoning better than that of the state and its adult experts. He knew. They did not. Will we listen any more attentively to the next sixyear-old who tells us that he knows what he wants and needs? It's not likely. ${ }^{7}$

The lesson of the Lindquist case (and the reason I bring it up) is that a child can be right. Even a six-year-old can know what is best for him, and can make wise choices. The emotional reaction a case like Johnny Lindquist's provokes may have limited its usefulness as a lesson. The Polovchak case, generating less passion, should stimulate more thought. But so far it has been a one-sided contest between patriotism and patriarchy, with the latter far ahead.

Is it appropriate, though, to compare the Polovchak case with Murgia and Bradley? What do these cases have in common? One similarity is that both parental control and compulsory retirement depend on generalizations about the capacities of certain age groups. State police officers must retire at fifty because society assumes that certain physical abilities decline with age, and that therefore a person over fifty is less likely than a younger person to have acute vision and fast reflexes. Likewise, parents have control over their children because society assumes that certain mental abilities increase with age, and that therefore a twelve-year-old is less able than an adult to make wise decisions. Each of these assumptions and generalizations is correct, to an appreciable extent; both are far more accurate than common generalizations about race or sex. The relationships between trait and abil-

6 "Children's Rights: The Latest Crusade," Time, December 25, 1972, p. 4I.

${ }^{7}$ Escape from Childhood (New York: Ballantine Books, 1975), pp. 174-75. Emphasis in the original. 


\section{The Question of Age}

ity are stronger in age discrimination cases than in those cases. Thus, although it is partly a matter of degree, age discrimination probably would not fall under the Frontiero definition of suspect classification.

But that is a probability, not a certainty, and the outcome may well depend on what age and what restriction. It is disquieting to compare Murgia with Frontiero and Craig. Brennan found sex-based distinctions suspect because, like race, sex is an involuntary, immutable characteristic. Age is mutable, but it, too, is "determined solely by the accident of birth." Brennan also discussed the lack of relationship between sex and ability, and the "gross, stereotyped distinctions" on which laws have often depended. ${ }^{8}$ Although the Court has refused to rank sex as a suspect classification, some of Frontiero survives as dogma. Later decisions have established that sex discrimination cannot be based on stereotyped assumptions. ${ }^{9}$ Rostker v. Goldberg weakens this principle only to the extent that the assumptions that have led Congress to exclude women from combat are used to justify their immunity to the draft. It remains to be seen how great a departure this ruling will be.

Murgia insisted that the retirement law is not based on such stereotyped assumptions, that there is good evidence that physical abilities decline with age. ${ }^{10}$ But even though these generalizations are supportable, they are not universally true. Some fifty-year-olds have perfect vision, just as some children have good judgment-or, at least, better judgment than adults around them. Nevertheless, the generalizations are universally applied; they include everyone within the group, with no exceptions.

When the Court declared in Murgia that the state police officers were not "subjected to unique disabilities on the basis of stereotyped characteristics not truly indicative of their abilities," it was dead wrong. ${ }^{11}$ That was exactly what had happened. The fact that the assumptions might be more accurate than some that have been made about blacks or women does not make them any less stereotyped. The fit between age and decline is no better than that between young manhood and drunken driving in Craig, and yet it was sufficient. Men, women, and racial minorities may not be restricted on the basis of gross stereotyped assumptions, but the old(er) and the young(er) may be.

Not only are the generalizations imperfect, but the abilities in question are imperfectly related to the facts of the particular cases. By and large, it is true that good vision and fast reflexes are useful for a police

\footnotetext{
${ }^{8}$ Frontiero v. Richardson, 4 I I U.S. 677, 686, 685 (1973).

${ }^{9}$ See Stanton v. Stanton, 42 I U.S. 7 (1975); Craig v. Boren, 429 U.S. I 90 (1976).

${ }^{10} 427$ U.S. 307, 313-14 (1976).

${ }^{11}$ Ibid., p. 3 I 3 .
} 


\section{Equality under the Constitution}

officer; to slip back into legal jargon, they are reasonably related to police work. But not all police tasks require them. ${ }^{12}$ Nor do all choices require "maturity" or "wisdom." Most choices are among few and limited things.

This discussion has suggested that certain typical age-based discriminations could survive standard equal-protection scrutiny. They are neither arbitrary nor suspect classifications. But Chapter 5 showed that another working definition of "suspect classification" exists, that is, classifications used to harm a distinct, isolated minority. Murgia insisted that classifications affecting those over fifty did not have this effect, and what was said there is equally true of youth. It is a stage of life we all go through; and though the young, too, must contend with prejudice and stereotype, to call them an oppressed or despised group strikes us as odd.

But this analysis, applied to youth, is no more satisfactory than it was in Murgia and Bradley. Age and youth are not typically thought of as brands, or deeply discrediting attributes in Goffman's sense, but it is easy to think of features that are similar to the stigma of blackness or femaleness. Both the old and the young partake of forced segregation, high visibility, lack of money and power, and, possibly, attitudes of accommodation (consider, for example, the "cute" behavior many children exhibit). Some of the worst stigmas do not seem to have equivalents here-for example, there is no ready counterpart to "nigger" or "broad" for children ("kid" does not make it, though "brat" might)-but the question seems to be one of degree. And the Murgia problem still exists: the fact that a general classification does not brand, isolate, or disempower does not foreclose the possibility that particular policies based on the classification can do so. In that sense, many such laws may put the weight of the government behind oppression.

I suggested that one way to create a disadvantaged group is to deprive its members of their jobs. When new jobs are not ready and waiting for retirees and pensions are often a joke, those who no longer work may virtually no longer eat. The deprivation is not of a "fundamental right" in the traditional sense, but it can be devastating. So are the potential effects of Walter Polovchak's being forced back home.

Bradley seems even more destructive than Murgia. I quoted at length from Justice White's opinion for the Court, in which he stressed the younger diplomats' morale at the expense of the older officers' jobs. I

\footnotetext{
${ }^{12}$ For an analysis of a similar issue that touches on some of these problems, see "Height Standards in Police Employment and the Question of Sex Discrimination: The Availability of Two Defenses for a Neutral Employment Policy Found Discriminatory under Title VII, " Southern California Law Review 47 (February 1974):585-640.
} 
questioned the assumption that the interests of one group could get absolute priority over those of the other. Something similar has happened in the Polovchak case. Comment on it has tended to emphasize the interests not of the child but of the parents. To some extent, of course, such comment is appropriate; the parents do matter. There have been suggestions, such as Goodman's, that the parents must be presumed to act in Walter's best interests. This assumption echoes Time's discussion-apropos, incredibly enough, of the Lindquist case-of "the psychic benefits of parental authority." ${ }^{13}$ But the decision to return Walter to his parents could hardly have been based only on his presumed interests. All too often it is assumed that parental authority is supreme; parental choice beyond question; parental priority absolute. With youth, as with age in the Bradley decision, law, doctrine, and opinion contain some disturbing assumptions about who really matters in this society and who does not.

Standard equal-protection doctrine deals summarily with maximum age rules, relegating them to the lower tier of classifications. The young fare even worse than the old with this doctrine; in cases involving children, equal-protection questions go all but unasked. The only such issue raised in the Polovchak case-Goodman hints at it in her column-is whether Ukranian parents get equal rights with American parents. In the decisions I shall examine, no judge seriously questions the government's power to treat children differently from adults. Children enjoy constitutional rights only to a very limited extent; they may be summarily punished and even injured; and demands may be made on children-for example, that they show respect or avoid bad company - that no adult outside a prison need tolerate.

Current doctrine thus buries questions of equality. But if one conceives of the constitutional guarantees as I have suggested-as broad provisions of equal respect and individual rights, transcending questions of capacity or competence-these issues do not bury easily. For the cases show that neither senior nor junior citizens enjoy these rights. They do not receive anything close to treatment as equals. They are not entitled to equality.

Before I examine cases on children, an introductory word is in order. The media have informed us selectively on these issues, distorting our perceptions. We hear of children who assault teachers, not teachers who assault children; teenagers who "pop" pills, not students forced to take them; juveniles who more or less get away with murder, not those incarcerated for years for behavior that adults get away with.

${ }^{13}$ “Children's Rights," p. 42. 
These distortions may reflect an ambivalence toward children, if not outright dislike. For readers unfamiliar with court decisions, much of the information here may be new and troubling.

\section{The Boundaries of Parental Control}

If the universality of the childhood experience (all of us were children once) could guarantee empathy from adult lawmakers despite the absence of children from legislative assemblies, there would be no occasion to regard children as an isolated and unrepresented minority, in need of special protection, but if adults instead look with contempt at a stage they have "outgrown" and will never re-enter, then every privilege withheld by legislators or administrators from the young must become a source of suspicion. ${ }^{14}$

The courts have come to question, though not to discard, any general presumption of adult benevolence they may have held with respect to officials. But parents are a different story. The judges never seriously question parental benevolence. Courts presume that parents are loving and wise. This notion expresses the ideal of family life, in which we have been taught to believe. But perhaps we do not need it taught to us. Since we all had parents, we have a stake in believing in the ideal; since many are parents, they have a double stake in a flattering vision of themselves.

But we do not really know how close the ideal comes to the reality of family life. The next four cases present much evidence of disjunction, but judges tend to discount these facts as "exceptions" to the rule. There are good reasons to challenge this dismissal. Certainly parents are instructed to love their children, and often do. The parentchild relationship may indeed be one of love, but it is inevitably one of power: not only because of the law, but because of parents' greater physical prowess and power of the family purse. For the feminist who has entertained the idea that the family may oppress women, it is only a small logical step to entertain, though not necessarily to embrace, the idea that it may also oppress children. But for many people, including judges, this is a foreign and frightening thought.

It was not until 1979 that the Supreme Court decided a case involving an overt conflict between parent and child. But parents are active participants in most cases involving children, usually on their chil-

\footnotetext{
${ }^{14}$ Laurence H. Tribe, "Childhood, Suspect Classifications, and Conclusive Presumptions: Three Limited Riddles," Law and Contemporary Problems 39 (special issue on children and the law, Summer 1975):9.
} 
dren's side. Some adult has to pay the lawyer's bill, and usually that person is the child's parent. Even when no fee is involved, some lawyers are reluctant to represent juveniles without parental approval. An example is the case of Paul Guilbert, a seventeen-year-old homosexual. In 1979 he sought to attend his high school junior prom in Cumberland, Rhode Island, with a male date. When the principal refused his request, the school committee denied Guilbert a hearing because his father opposed him. The Providence chapter of the ACLU refused to take the case for the same reason. The next year, however, Guilbert attended the senior prom with the same date. Aaron Fricke was eighteen and legally an adult, so he could bring suit on his own. A federal district judge ruled in his favor. School officials considered canceling the prom, but let it go on as scheduled. There were no incidents. ${ }^{15}$

Usually cases involving children are brought by the parent, acting as the child's "next friend." ${ }^{16}$ As a result, the typical case carries an assumption that the interests of parent and child are identical. But, as two landmark cases show, there may be reason to wonder.

In Wisconsin v. Yoder, only Justice Douglas did wonder. He joined his eight colleagues in ruling that Old Order Amish parents could remove their children from school after the eighth grade, as their religion required, when the children agreed; but he dissented alone when there was no record of the child's wishes. Douglas cited data that showed that an appreciable number of Amish children do eventually leave their community; would they not need further schooling ${ }^{17}$ Education is enabling; it equips people to make decisions about their lives, and stopping it at an early age limits individual freedom-which, of course, is just what the Amish parents want. However healthy, virtuous, and law-abiding the Amish way of life is, it is also constricting, and there is evidence of severe problems behind the facade of "idyllic agrarianism." ${ }^{18}$ No one disputes an adult's right to choose such a life, but may parents effectively foreclose all other choices for their child? On the other hand, if parents do not limit the child's alternatives, will the child ever again be able to make that particular choice? The fact that ever larger numbers of young adults choose to live under strict religious discipline suggests an affirmative answer to the second question.

\footnotetext{
${ }^{15}$ New York Times, April I I, 1979, p. I7; April I3, p. I0; April I6, III, p. I 2; April 22, p. 29; May 21, 1980, II, p. 4; May 29, II, p. 8; May 31, p. 26. But see Buckholz v. Leveille, 194 N.W. $2 \mathrm{~d} 427$ (Mich. C. App., 197I), where a high school student was allowed to bring suit over his parents' objections.

${ }^{16}$ I.e., the closest legally competent person; however, an adult other than a parent may bring an action as a child's next friend.

${ }^{17} 406$ U.S. 205, 245, n. 2 (1972).

${ }^{18}$ State v. Yoder, 182 N.W. 2d 539, 549-50 (Heffernan dissenting).
} 
In Yoder, such questions are visible but not readily answerable. In an equally famous case, Tinker v. Des Moines Community School District, they were not even visible. ${ }^{19}$ When three students were suspended for wearing black armbands to protest the Vietnam war, their parents went to court and won. No one saw any possible conflict. But Robert Burt, writing several years later, questioned whose First Amendment rights the decision actually protected: the children's or the parents'. A good question: many of us can recall adolescent embarrassment at our parents' political beliefs. Burt does not think this parent-child conflict was appropriately presented to the Court in either Tinker or Yoder; he argues that both were rightly decided. ${ }^{20}$ But the general question will not go away.

Parham v. J. R. presented it squarely. ${ }^{21}$ At issue was the commitment of minors to state mental institutions on the request of their parents or guardians. The institutions' authorities had to approve the commitment, but no formal hearing was required either before or after admission. A three-judge district court in Georgia had enjoined this practice, ruling that giving parents "unbridled discretion" violated due process. The judge repeatedly compared this case with Gault, in which the Supreme Court had held that the requirements of notice, hearing, and counsel apply to juvenile court proceedings. He pointed out that, in fact, Georgia's juvenile code had more safeguards than this law, that institutionalization could be as harmful as imprisonment, and that "there are no true 'voluntary' child admissions." 22 Judge Wilbur Owens also relied on another apposite case, O'Connor v. Donaldson. ${ }^{23}$ There the Supreme Court had unanimously ruled that to confine a nondangerous patient against his will violated due process. Kenneth Donaldson had been committed-by his parents, note, but after a court hearing - in 1957, and, despite repeated efforts to secure his release, was held, with no further hearing, until 1974.

Explaining his reliance on these two cases, Judge Owens quoted a doctor's description of a "typical" decision to commit: "The parent may come in saying, 'I can't handle it any more; do something.' And they say at the hospital . . . 'I think hospitalization is indicated.' The

${ }^{19} 393$ U.S. 503 (1969).

20 "Developing Constitutional Rights of, in, and for Children," Law and Contemporary Problems 39 (Summer 1975): I22-32.

${ }^{21} 99$ S.Ct. 2493. See also the companion case, Secretary of Public Welfare v. Institutionalized Juveniles, 99 S.Ct. 2523.

${ }^{22}$ J. L. [sic] v. Parham, 4I 2 F. Supp. I I 2, I 2 I (M.D. Ga. 1976), citing the Report of the Georgia Study Commission on Mental Health Services for Children and Youth, 1973.

${ }^{23} 422$ U.S. 563 (1975). 
parent would agree and that would be it." The judge concluded: "To unnecessarily confine a child in a mental hospital and thereby cause him to possibly suffer severe emotional and psychic harm, to demean himself, and to magnify social ostracism, is to deprive him of a child's freedom just as much as if not more so than a child is deprived of his freedom by being civilly committed as a juvenile delinquent." ${ }^{24}$

The Supreme Court reversed. All that due process required, declared Chief Justice Burger, was "some kind of inquiry ... by a neutral fact finder ... [ [which] ... must also include an interview with the child." The decision maker must "have the authority to refuse to admit any child" and "the child's continuing need for commitment" must "be reviewed periodically by a similarly independent procedure." 25 The psychiatrists and administrators provided such a review.

One might question whether an employee of mental institution is in fact "neutral." The choice to work in such an institution presumably implies approval of that mode of treatment. ${ }^{26}$ But the most striking features of Burger's opinion were its endorsement of both the therapeutic model of mental institutions and the traditional model of the family.

The state through its voluntary commitment procedures does not "label" the child: it provides a diagnosis and treatment that medical specialists conclude the child requires. In terms of public reaction, the child who exhibits abnormal behavior may be seriously injured by an erroneous decision not to commit. Appellees overlook a significant source of the public reaction to the mentally ill, for what is truly "stigmatizing" is the symptomatology of a mental or emotional illness.

All this would be news to Kenneth Donaldson, who was incarcerated for seventeen years with little treatment or symptomatologynot to mention Senator Thomas Eagleton, forced to withdraw in 1972 as the Democratic vice-presidential candidate because he had been in a mental hospital. Hospitalization is not inevitably therapeutic, and, worse, it can be stigmatizing-even for U.S. senators. It is impossible to determine whether Eagleton's electroshock treatments helped him; what is certain is that they branded him.

Burger's ideas about family relationships were not quite so sanguine, but they, too, had a benevolent image of authority.

${ }^{24} 4$ I 2 F. Supp. I I 2, I 34, I 36-37.

${ }^{25}$ Parham v. J. R., 99 S.Ct. $2493,2506$.

${ }^{26}$ There is evidence that psychiatrists tend to err on the side of commitment. See "The Supreme Court, 1978 Term," Harvard Law Review 93 (November 1979):95-96. The Georgia Commission found that over half the children committed did not require institutionalization. 


\section{Equality under the Constitution}

Our jurisprudence historically has reflected Western Civilization concepts of the family as a unit with broad parental control over minor children. Our cases have consistently followed that course; our constitutional system long ago rejected any notion that the child is "the mere creature of the State" and, on the contrary, asserted that parents generally "have the right, coupled with the high duty, to recognize and prepare [their children] for additional obligations." Surely, this includes a "high duty" to recognize symptoms of illness and to seek and follow medical advice. The law's concept of the family rests on a presumption that parents possess what a child lacks in maturity, experience, and capacity for judgment required for making life's difficult decisions. More important, historically it has recognized that natural bonds of affection lead parents to act in the best interests of their children.

... that some parents "may at times be acting against the best interests of their children" . . creates a basis for caution, but is hardly a reason to discard wholesale those pages of human experience that teach that parents generally do act in the child's best interests. The statist notion that governmental power should supersede parental authority in all cases because some parents abuse and neglect children is repugnant to American tradition. ${ }^{27}$

Whether or not parents "generally" act in their child's best interests is a question incapable of resolution. Burger has accurately stated what has been assumed, not shown. One reason that parents are assumed to act this way must be that we can frequently observe them doing things that are obviously good for their children. But when a parent does something that appears harmful, should we assume that the parent is acting in the child's interests? Do we assume so when we see a child being hit hard? Even if the parent insisted that the blows were for the child's own good, should we believe this explanation?

Civil commitment is not so clearly harmful as those actions that, inflicted by anyone but parents or school officials on anyone but children, would constitute assault. But the lower court records suggest that hospitalization can hurt children, that the commitment of children for their own good does not make it for their own good. Motive does not determine effect, and even if it did, the typical precommitment conversation is not reassuring about motive. Nor is Parham's companion case from Pennsylvania. There the district court judge reviewed the records of the twelve children involved. Three had exhibited violent or self-destructive behavior, but two were admitted because they were "hyperactive," one because of a history (but no convictions) of "stealing and destroying property," and another for

${ }^{27} 99$ S.Ct. 2493, 2503-4. Emphasis added. The interior quotes are, respectively, from Pierce v. Society of Sisters, 268 U.S. 5 I0, 535 (1925); and Bartley v. Kremens, 402 F. Supp. 1039, 1047-48 (E.D. Pa. 1975). Emphasis in the original. 
"making weird noises, refusing to do work, and talking back to teachers." 28 (These descriptions also call into question the "neutral factfinders'" powers of discrimination.) Generalities to the effect that parents act in their children's best interests should not govern cases in which such evidence exists to the contrary.

Also beside the point is any "statist notion" of governmental supremacy. Burger has cited two cases, Pierce v. Society of Sisters and Meyer v. Nebraska, which upheld the parents' rights against the state in order to uphold the parents' rights against their children. ${ }^{29}$ Here the state does not choose between involvement and noninvolvement; what it is asked to do is to admit a child into one of its institutions. Whatever happens, state power is involved. Burger's rhetoric might be appropriate if a state committed a child without parental approval, but not when the state's choice is between using its power to admit a child and using its power to refuse. Surely the state has no duty to commit a child on a parent's request.

And it is not clear just how strong the justices' commitment to parental authority is. In another article, Robert Burt examines Parham in relation to several other cases. He points out that Burger, Powell, and Rehnquist voted against parents who protested their children's suspension from school or the imposition of corporal punishment, while supporting parental consent for abortion and concurring in Parham and Yoder. ${ }^{30}$ Burt infers that for these justices "a specific authoritarian style of parenthood, rather than the status of a parent itself, warrants constitutional deference." ${ }^{31}$

Chief Justice Burger wrote not only of parents, but of children too, in traditional terms. "Most children, even in adolescence, simply are not able to make sound judgments concerning many decisions, including their need for medical care or treatment. Parents can and must make these judgments." ${ }^{32}$ The Lindquist case, easy as it is to dismiss as an "exception," casts some doubt on that general principle. My

\footnotetext{
${ }^{28}$ Institutionalized Juveniles v. Secretary of Public Welfare, 459 F. Supp. 30, 36-38 (E.D. Pa. 1978).

${ }^{29} 268$ U.S. $510 ; 262$ U.S. 390 (1923).

${ }^{30}$ Goss v. Lopez, 419 U.S. 565 (1975); Ingraham v. Wright, 430 U.S. 651 (I977); Planned Parenthood of Central Missouri v. Danforth, 428 U.S. 52 (1976).

31 "The Constitution of the Family," Supreme Court Review, 1979, p. 340.

${ }^{32}$ Parham v. J. R., 99 S.Ct. 2493, 2504-5. What is true of commitment is, apparently, partially true of abortion. H. L. v. Matheson, Ior S.Ct. I I64 (I98I), upheld a Utah law requiring parental notification, but not consent, before a minor's abortion. Burger, again writing for the Court, expounds the same generalities about minors' general incompetence and parents' benevolent omniscience as in Parham. Since the Parham ruling is more to the point, involving actual coercion rather than consultation, I have retained it as my major example of decision making in this area.
} 
discussion of the Polovchak case shows that many of the disabilities of children are not caused by their immature minds but are imposed from outside. As psychologist Richard Farson puts it, "We cannot assess the potentialities of children because we have never organized society to elicit them. We have probably done just the opposite." ${ }^{33}$

And an old problem, one that Jefferson saw, remains. Whether or not people are competent to rule themselves, can anyone else rule them? That was the crucial problem in the next three cases. It is unlikely that any of these children were competent to make the decisions that had to be made. The trouble was that neither were their parents.

It is an established rule that parents have the duty to provide children with necessary medical care. ${ }^{34}$ When parents refuse to provide such care-for religious reasons, for example-the state will intervene. But what happens when parents reject medical advice in regard to treatment of children with life-threatening illnesses? That was the issue in the next two cases. Although the rulings differed, the results were the same: the parents prevailed and the children died.

In August 1977, twenty-month-old Chad Green was diagnosed as having acute lymphocytic leukemia. His doctors in Omaha, Nebraska, prescribed conventional chemotherapy, with which, according to their testimony, his chances of survival were slightly better than 50 percent. Chad was in remission within a month. The family moved back to his father's hometown, Scituate, Massachusetts, so Chad could be treated at the Massachusetts General Hospital. The chemotherapy and the remission continued, but in November the Greens stopped giving Chad medication without telling the doctors. They began a program that "included dietary manipulation and prayer" as well as vitamins and Laetrile. Chad soon had a relapse. The parents admitted they had stopped the chemotherapy, but refused to start it again.

... according to the mother's testimony, the decision to terminate chemotherapy was not based on the parents' view that another medically effective form of treatment could be found. Rather, it reflected the parent's deep concern over the child's discomfort in the chemotherapy program, and their pessimism concerning the child's chances for cure.... The mother stated, "We would love for Chad to have a full and long life. But it is more important to us that his life be full instead of long, if that [is] the way [it has] to be." ${ }^{35}$

33 “The Children's Rights Movement," in LaMar T. Empey, ed., The Future of Childhood and Juvenile Justice (Charlottesville: University Press of Virginia, 1979), p. 43.

${ }^{34} 59$ Am. Jur. 2d, Parent and Child, sec. I 5 (1962).

${ }^{35}$ Custody of a Minor Child, 379 N.E. 2d I053, 1064 (S.J.C. Mass., 1978). 
The hospital got a temporary restraining order, resumed the treatment, and got Chad back into remission. Even after his relapse, he had about a 50 percent chance of full recovery. When the Supreme Judicial Court upheld the order, the Greens left the state and petitioned for review. The court ordered them to return Chad, but they did not. ${ }^{36}$ Chad died in Omaha in 1979.

The court emphasized the fact that there was no medical testimony in favor of the Greens' therapy, and that the hospital's uncontradicted medical testimony stated that chemotherapy would give Chad a good chance for a normal life. ${ }^{37}$ (Good, yes; but, after all, a 50 percent chance of survival is also a 50 percent chance of death.) In the first case, the judge suggested that so young a child was unable to understand why he was being subjected to the effects of the chemotherapy, and could not be allowed to make such a decision himself. But Chad never expressed an opinion, and at any rate, the side effects were limited to constipation and stomach cramps, which were relieved with medication. ${ }^{38}$

Although no one who saw the Greens on television can question their sincerity or their ultimate grief, their actions are hard to accept. As the second decision said, "It is with sadness that we review the entire history of this case... The judgment of the parents has been consistently poor, from the child's standpoint, and his well-being seriously threatened as a result." ${ }^{39}$

Joseph Hofbauer's parents won in the New York Court of Appeals, though not before they had left its jurisdiction. The facts were not identical to those of the Green case. Joey had Hodgkin's disease, not leukemia. The evidence in favor of nutritional therapy was better, but so were the boy's chances of survival with chemotherapy. (The fact that Joey was seven rather than one made no difference, ever). The Hofbauers were clear and explicit about their reasons for preferring Laetrile. They wanted to avoid the nauseous effects of traditional drugs, which Joey's father graphically described on national television. The parents appeared more optimistic about the future than the Greens had been. The court saw the matter this way:

It surely cannot be disputed that every parent has a fundamental right to rear its child. While this right is not absolute inasmuch as the State, as

\footnotetext{
${ }^{36}$ Custody of Minor Child, 393 N.E. 2 d 836 (1979).

${ }_{37}^{37} 39$ N.E. 2 d 1053 , 1056, 1065; 393 N.E. $2 d 836,841-46$.

38379 N.E. 2d 1053, 1066, 1064. The parents alleged there were psychological side effects as well, but they were never shown.

${ }^{39} 393$ N.E. 2 d 836, 846.
} 


\section{Equality under the Constitution}

parens patriae, may intervene to ensure that a child's health or welfare is not being seriously jeopardized by a parent's fault or omission, great deference must be accorded a parent's choice as to the mode of medical treatment to be undertaken....

... Ultimately ... the most significant factor in determining whether a child is being deprived of adequate medical care, and, thus, a neglected child within the meaning of the statute, is whether the parents have provided an acceptable mode of treatment for their child... . This inquiry cannot be posed in terms of whether the parent has made a "right" or a "wrong" decision. . . . Rather, in our view, the court's inquiry should be whether the parents, once having sought accredited medical assistance and having been made aware of the seriousness of their child's affliction and the possibility of cure if a certain mode of treatment is undertaken, have provided for their child a treatment which is recommended by their physician and which has not been totally rejected by all responsible medical authority. ${ }^{40}$

Since the Hofbauers had found several doctors who prescribed Laetrile, and they and others had testified that Joey's illness was under control, the court denied the state's petition to have Joey declared a neglected child. But the opinion gives a one-sided presentation. State physicians who had examined Joey testified that his disease was progressing. ${ }^{41}$ There was no discussion of his chances of recovery with conventional treatment, which were fairly good. Nor was there a report of any victim of Hodgkin's recovering with Laetrile. It is easy to criticize the decision now, when we know that Joey died, but even without this hindsight, the court seems to be stretching to defend, or at least accept, the parents' judgment. Like Chief Justice Burger in Parham, the judges recite traditional generalizations about parents and children. And the word "fundamental" is used to describe a parent's rights, as if they stood on their own, separate from the child himself.

That was also true in a case brought to the Supreme Court a year after Parham. The Court denied review, although the case was literally a matter of life and death. The story of Phillip Becker has been at least as widely publicized as those of Chad Green, Joey Hofbauer, and Walter Polovchak; 6o Minutes has devoted a segment to him. Phillip, now fourteen, has Down's syndrome, and has lived in a California residential facility since his birth. He has a heart defect common in Down's victims. His doctors wanted to perform corrective surgery, but his parents refused permission. The state courts upheld the parents, and the justices' action leaves the ruling in effect. In I98I, however, a state

\footnotetext{
${ }^{40}$ Matter of Hofbauer, 393 N.E. 2d I009, I013-14 (1979). This case was decided before the second Green case, not afterward.

${ }^{41}$ Ibid., p. IOI 2.
} 
superior court judge awarded custody of Phillip to a couple who had done volunteer work at the home where he lived and who want the surgery performed. ${ }^{42}$ I shall discuss this case at greater length in Chapter 8 , but a comment of the trial judge is appropriate here. He stated, "The principle of parental autonomy is fundamental." ${ }^{43}$ But surely it is not. Parental rights, as even Chief Justice Burger declares in Parham, are derivative, from the presumed incompetence of the juveniles and the parental dedication to the child's interests. ${ }^{44}$ To rank them as fundamental is a serious distortion.

There is, of course, an important difference between Parham and Phillip $B$. and the Green and Hofbauer cases. Because media coverage was so extensive, there is ample evidence of these parents' good intentions. They acted and felt as Burger assumes most parents act and feel. But however good their intentions, the end results were the same as in the Lindquist case. Their decisions may have forfeited, and probably shortened, their children's lives. Their actions did at least as much damage as those of exasperated or even malevolent parents who commit their children. After Joey's death, his father called him "a pioneer whose purpose was to establish the right of parents to make these decisions for their children and to keep Governor Carey and his faceless bureaucrats out of the family." ${ }^{45}$ But was this child a pioneer, or a sacrifice?

This group of cases has some disturbing implications. They show that, as far as parental control is concerned, there is little difference betwen a toddler like Chad Green and a twelve-year-old like Walter Polovchak. A child Walter's age can read, and may form opinions about medicine; after all, cancer and its treatment are becoming staple fare in mass-circulation magazines. If a stricken twelve-year-old preferred chemotherapy to Laetrile, Hofbauer could be used as precedent-and in New York State would have to be so used-for ruling against her.

Chad Green's case points up another worrisome aspect of these situations: that the children involved were not necessarily better off with decisions against their parents. The Greens left Massachusetts, and were able to get away with defying a court order even with wide publicity. Parents in future cases will probably have similar success, especially since they are now likely to leave before the decision, as the

\footnotetext{
${ }^{42}$ In re Phillip B. (and Bothman v. Warren B.), App., I 56 Cal. Rptr. 48 (Ct. App., Ist D., I979); Bothman v. Warren B., cert. den., I00 S.Ct. I 597 (1980); "Parents Bar Surgery and Lose Son's Custody," New York Times, August 9, I98I, p. 2 I.

${ }^{43}$ Quoted on 60 Minutes, CBS-TV, January $198 \mathrm{I}$.

${ }^{44} 99$ S.Ct. 2493, 2504-5 (1979).

${ }_{45}^{45}$ Walter H. Waggoner, "Boy, Io, in Laetrile Case Dies," New York Times, July I 8, 1980, IV, p. 5 .
} 
Hofbauers did. In fact, there was no one to intervene between Chad and his parents, to provide the care a young child needs, so Chad was as helpless as Walter Polovchak would be without his relatives.

Similarly, a child whose parents fail in their commitment efforts is almost certainly better off than one whose parents succeed, but being in the custody of angry, resentful parents is itself at best an unhealthy situation. Courts may be able to prevent some parental errors and abuses, but they cannot make the children autonomous. The children's freedom is limited by incapacity, whether real or superimposed. Nevertheless, it is possible that some parents would not flee after a court order; that some children would find other adults to take responsibility for them; that some parents would seek help outside an institution. The decisions, which emphasize parents' rights and children's incompetence as if it were impossible to transpose the possessive modifiers, foreclose these possibilities. Where society works hard to keep minors dependent, courts cannot free them; but we might hope that when they get through cracks in the system to gain some independence, courts will not frustrate them.

If the courts' idealized view of parents were correct, it would not matter too much how competent or incompetent children are. Wise, benevolent parental despots could reinforce their children's competence and protect them from their incompetence. If parents were such angels in the form of kings and queens, these decisions would not endanger children's rights to equality. But would such parents be likely to put their unwilling children in institutions? The best evidence against the Burger-Goodman view of the family is that any of these cases arose at all. Even if the fallible parent is an exception, it is, after all, exceptional cases that get to court. Repeated affirmations of parental power ensure that children do not get equal protection.

\section{The Law of the School}

Every parent and child in the United States is subject to compulsory education laws. All states, territories, and the District of Columbia require children within a fixed, and wide, age range to attend school, and parents to see that they do. Parents have wide discretion over their children's schooling. They are free to choose among public, private, and parochial schools, and have some control over the curriculum. ${ }^{46}$

\footnotetext{
${ }^{46}$ Pierce v. Society of Sisters, 268 U.S. 5 I0 (1925); Meyer v. Nebraska, 262 U.S. 390 (1923).
} 
But except when their religious freedom is involved, as in Yoder, parents must get their children to school.

Going to school may be the only thing the state makes all of us do. It has affected far more people than the draft did. Like the draft, compulsory schooling has become controversial, though not to the same degree. ${ }^{47}$ But despite the strong arguments of some opponents, I am dubious about the wisdom of abandoning it. If six-year-olds were free to make choices about where to spend their time, the case for abolition might be stronger, but I think I have said enough about the ways in which children are disempowered to show that they are not free. If school were not compulsory, parents could find all sorts of reasons, bad, selfish, ignorant, or misguided, for keeping their children out. If school were only prison or conscription, we might turn a blind eye to such parents, but school is more than coercion. It teaches skills, and if these skills do not quite liberate, they do empower. There probably should be some alternatives to traditional schooling, but some compulsory education seems necessary in a society that does not ensure that we learn these skills on our own. Of course, to the extent that schools fail to teach, the case for compulsory attendance is weakened. Where there is no education, "compulsory school attendance functions as a bill of attainder against a particular age group." ${ }^{48}$ Even when schools do their job, it seems logical that the fact of compulsion demands more lenience, not more stringency, from the officials who do the compelling.

If schools are not "bad places for kids," they are places where bad things can happen to them. ${ }^{49}$ They often do not learn the skills they are there to learn, while they pick up misleading information, misinformation, and muddled thinking habits. ${ }^{50}$ Students may learn "lessons in Practical Slavery," automatic obedience, racism, and sexism. They may be given drugs to cure their "hyperactivity"; whatever the overall merit of this treatment, it is misused and overused. ${ }^{51}$ As Tinker

\footnotetext{
${ }^{47}$ See, e.g., Richard Farson, Birthrights (New York: Macmillan, 1974), chap. 7; Edgar Z. Friedenberg, The Dignity of Youth and Other Atavisms (Boston: Beacon Press, 1965); John Holt, The Underachieving School (New York: Pittman, 1969); Ivan Illich, Deschooling Society (New York: Harper \& Row, 1971).

${ }^{48}$ Friedenberg, Dignity of Youth, p. 90.

${ }^{49}$ Holt, Underachieving School, pp. I 5-34.

${ }^{50}$ See, e.g., Neil Postman, Teaching as a Conserving Activity (New York: Delacorte, 1979); Neil Postman and Charles Weingartner, Teaching as a Subversive Activity (New York: Delta Books: 1969); Charles E. Silberman, Crisis in the Classroom (New York: E. Silberman, Crisis in the Classroom (New York: Vintage Books, 1970).

${ }^{11}$ Holt, Underachieving School, p. 19. See, e.g., Friedenberg, Dignity of Youth; Coming of Age in America (New York: Random House, 1965); or The Vanishing Adolescent (Boston: Beacon Press, 1959); James Herndon, The Way It Spozed to Be (New York:
} 


\section{Equality under the Constitution}

showed, schools have deprived children of so unobtrusive a mode of expression as wearing an armband. Although the Supreme Court invalidated this action, and other decisions have protected such activities as distributing "underground" publications and wearing "freedom buttons," the school may respond to "commotion and confusion" by banning the buttons. Black students may be subjected to such public insult as hearing "Dixie" played at a pep rally. Students may be punished in a variety of ways: sent outside the classroom, ridiculed, kept after school, suspended, and beaten. ${ }^{52}$ School does provide a counterforce to parental authority, but it also subjects the child to yet another power.

Even without the footnotes, the reader has probably recognized several court decisions in the above list. I have already mentioned one of them; it is hard to discuss parental authority without getting into schools, just as it is hard to discuss the rights of children, handicapped people, and homosexuals without overlapping. Here, at least, everything is related to everything else.

Tinker has been recognized as a landmark case in students' rights. It does extend the protection of the First Amendment to the classroom, and that is important. The majority opinion declared: "It can hardly be argued that either students or teachers shed their constitutional rights to freedom of speech or expression at the schoolhouse gate." The Court had no difficulty in concluding that wearing an armband was a "symbolic act" within the free-speech clause. But there was equal emphasis on the school authorities' power not just to preserve safety but to keep to business as usual. The appropriate test for deciding whether an act was protected by the First Amendment was whether "the students' activities would materially and substantially disrupt the work and discipline of the school." Here there was no disruption, only "worry." 53

So far, so good. But what is so bad about disruption? Recall the words of Justice Douglas in Terminiello v. Chicago: "A function of free speech under our system of government is to invite dispute. It may

Simon \& Schuster, 1968); Herbert Kohl, 36 Children (New York: New American Library, 1967); Jonathan Kozol, Death at an Early Age (Boston: Houghton Mifflin, 1967); Barbara Grizzutti Harison, Unlearning the Lie: Sexism in School (New York: Liveright, 1973); Letty Cottin Pogrebin, Growing up Free (New York: McGraw-Hill, 1980), chap. 23; Judith Stacey et al., eds., And Jill Came Tumbling After: Sexism in American Education (New York: Dell, 1974); Diane Divoky and Peter Schrag, The Myth of the Hyperactive Child (New York: Pantheon, 1975).

${ }^{52}$ Vail v. Board of Education, 354 F. Supp. 592 (D.N.H. 1973); Burnside v. Byars, 363 F. 2d 744 (5th Circ. 1966); Blackwell v. Issaquena County Board of Education, 363 F. 2 d 749 ( 5 th Circ. 1966); Tate v. Board of Education, 453 F. 2d 975 (8th Circ. I 972 ); Goss v. Lopez, 4 I 9 U.S. 565 (1975); Ingraham v. Wright, 430 U.S. 65 I (I977).

${ }^{53} 393$ U.S. 503, 506, 513, 510 (1969). 
indeed best serve its high purposes when it induces a condition of unrest, creates dissatisfaction with conditions as they are, or even stirs people to anger." 54 Tinker implies that the school's interest in discipline overrides these interests, but may not exactly the opposite be true? Is it not especially important to have such expression in the schools, where children have to be, and where they are supposed to learn to be citizens?ss

Freedom of speech is not all that children lose in school. An old joke in the public law field describes the difference between procedural and substantive due process as that between how you get screwed and whether you get screwed. The same distinction appears in the public law of the school. The First Amendment cases belong in the "whether" category, but there are plenty of "how" cases, too. School discipline has been a recurring issue. In 1975, in Goss v. Lopez, the Supreme Court upheld an Ohio ruling that the due-process clause of the Fourteenth Amendment extended to suspensions and expulsions. ${ }^{56}$

This case was the result of a class action challenging suspension in two senior high schools and one junior high in Columbus during a period of student unrest centering on Black History Week. This unrest had been manifested in several demonstrations, during which some property was destroyed and a police officer was attacked. Nine students had been suspended, without hearings, for up to ten days. Two students had testified that they were given no opportunity to tell their side of the story; a third said that she could not get into class at all because of the disruption.

State law required the school to notify the students' parents within twenty-four hours of any suspension or expulsion, and to give parents the reason for such action. The principal at one high school sent letters to the parents, scheduling a conference among parents, student, and officials at a date and time set by the principal. The parents, however, could not get into the school at the scheduled time because the demonstrations were still going on. A student at the other high school was suspended after she tried to get excused from classes, telling the principal that her mother had told her to come home if there were any disturbances. The letter to her parents said that she "showed a lack of respect for the principal." 57

${ }^{54} 337$ U.S. I, 4 (1949).

${ }^{55}$ This is especially true in Blackwell v. Issaquena County Board of Education (upholding a school's right to ban "freedom buttons") and Tate v. Board of Education (denying the right of black students not to be publicly insulted by the playing of "Dixie" at a school function).

${ }_{56}^{51} 19$ U.S. 565 ; Lopez v. Williams, 373 F. Supp. 279 (S.D. Ohio 1973).

${ }^{57} 373$ F. Supp. I $284-88 ; 419$ U.S. $565,568-7$ I. 


\section{Equality under the Constitution}

This narrative conveys some of the flavor of school life: the authoritarianism, the arbitrary orders, and the omnipresent double bind. But for the courts, that was not the point. What violated the due-process clause was the denial of notice and hearing. "We hold only that, in being given an opportunity to explain his version of the facts at this discussion, the student first be told what he is accused of doing and what the basis of the accusation is." ${ }^{8}$ The hearing could be informal and immediate. If some physical danger prevented such action, notice and rudimentary hearing must follow as soon as possible. Counsel was not required, nor was the right to call or confront witnesses, but the Supreme Court left open the question of whether these rights should be required for longer suspensions or expulsions.

Lopez was a 5-to-4 decision. For the majority, Justice White emphasized the harmful effects of suspensions. Not only were ten days of classes lost, but the charges could damage the student's relationships with faculty and other students, and later, employment opportunities. "It is apparent," White wrote, "that the claimed right of the state to determine unilaterally and without process whether that misconduct has occurred immediately collides with the requirements of the Constitution." 59

Lopez is an important protection for students, but it leaves untouched the substantive component of school discipline. "Lack of respect," something for which no adult could be punished by the state, may still be an offense. Furthermore, the closeness of the vote suggests a need to look at minority opinions-at least, it does in retrospectand this look is not encouraging. Justice Powell wrote a dissent that was endorsed by Burger, Blackmun, and Rehnquist. Powell's insistence that ten days' absence from school- "less than $5 \%$ of the school year"-is not an injury to education can be dismissed as both incorrect and unresponsive to much of White's opinion. More ominous is the impression given that four members of the Court, none of whom was there when Tinker was decided, are unwilling to place any limits on the power of school officials: "In prior decisions, this Court has explicitly recognized that school authorities must have broad discretionary authority in the daily operation of public schools. This includes wide latitude with respect to maintaining discipline and good order." 60

It was Powell who wrote for the Court in Ingraham v. Wright. ${ }^{61}$

\footnotetext{
${ }^{58} 419$ U.S. $565,580-82$.

${ }^{59}$ Ibid., p. 575.

${ }^{60}$ Ibid., pp. 589-90.

${ }^{61} 430$ U.S. 65 I (1977).
} 
Here the Court ruled on corporal punishment in the schools. This practice had been the subject of several federal district court decisions, all of which had sustained it, although one ruling had provided for an exception when parents had notified school authorities in advance that they did not want their children hit. ${ }^{62}$ Of course, the fact that parents brought all of these actions indicates that none of them wanted corporal punishment imposed on their children.

Ingraham came to the Court from Dade County, Florida. Its board of education authorized corporal punishment under the following conditions: the teacher must first consult the principal; another adult must be present; no blows were allowed above the waist or below the knees, and none that would produce physical injury [sic]. There was no requirement for hearing or parental notice. As late as 1970, the practice was fairly common. The student was usually paddled "one to five 'licks' or 'blows'" on the buttocks with a flat wooden instrument. The rules about notifying the principal and having another adult present were often violated. ${ }^{63}$

The rules about the beating itself were also violated, at least in the two instant cases. When James Ingraham and several other students failed to leave the school auditorium quickly enough to suit their teacher, they were paddled in the principal's office. James got at least twenty blows, and was out of school for several days. Roosevelt Andrews was hit on the arm; he could not use that arm for a week. ${ }^{64}$ Both children's parents brought suit.

Neither the Court of Appeals nor the Supreme Court found any constitutional violation. Corporal punishment was not "cruel and unusual" under the Eighth Amendment, nor did the due-process clause require notice and hearing. The Court of Appeals had distinguished this case from Lopez: "We believe that there is an important distinction ... between a suspension, which involves an exclusion from the educational process itself, and a paddling, which involves no deprivation of a property interest or a claim to education and is certainly a much less serious event in the life of a child than is a suspension or an expulsion."65

Justice Powell, now writing for the majority, did not stress Lopez at all. His argument echoes some long-obsolescent due-process deci-

${ }^{62}$ Glaser v. Marietta, 35 I F. Supp. 555 (W.D. Pa. 1972). The other cases are Ware v.. Estes, 328 F. Supp. 657 (N.D. Tex. I97I); Sims v. Board of Education, 329 F. Supp. 678 (D.N.M. 197I); Gonyaw v. Gray, 36 I F. Supp. 366 (D. Vt. 1973); Baker v. Owen, 395 F. Supp. 294 (M.D.N.C. 1975); affirmed without opinion, 423 U.S. 907.

${ }_{63}^{63}$ Ingraham v. Wright, 498 F. 2d 248, 254-56 (5th Circ. 1974).

${ }^{64} 430$ U.S. $65 \mathrm{I}, 657$.

${ }^{65}$ Ingraham v. Wright, 525 F. 2d 909, 918-19 (5th Circ. 1976). 


\section{Equality under the Constitution}

sions. Powell emphasized the sorts of consideration that had been prominent in such cases as Twining v. New Jersey and Wolf v. Colorado. ${ }^{66}$ Corporal punishment was sanctioned by common law, has persisted in schools throughout American history, and is still recommended by some authorities. ${ }^{67}$ His conclusion that it is not cruel and unusual rests chiefly on this evidence.

A decision that the Dade County regulations were constitutional on their face would not necessarily have settled the controversy. The Court could still have ruled that the regulations had been applied (no pun intended) in violation of constitutional rights. But the majority would not even entertain this possibility. Parts of the opinion read like Irvine v. California. ${ }^{68}$ Any abuses, it suggested, might have remedies other than constitutional adjudication: civil suit, perhaps, or state-imposed criminal penalties. ${ }^{69}$ Time had proved that notion disastrously wrong with respect to police abuses. But it appears that learning a lesson once is not enough.

How can we explain this obtuseness? Has the Court forgotten how wrong those old decisions proved to be? The problem may be that the Court does not see any similarity between corporal and criminal punishment. The schoolchild, we are told, has "little need" for the protection of the Eighth Amendment. ${ }^{70}$ Unlike prison, school is an open institution (except that children have to go there); the child is not physically restrained (except by truancy laws and the need to ask permission to move within or out of the classroom); and at the end of the day the student, unlike the prisoner, returns home.

We are verging here on the fantastic. If the child has little need for protection in school, how did it happen that these two boys were so badly injured there? Their injuries show the need for protection. As Justice White wrote in dissent, "... the record reveals beatings so severe that if they were inflicted on a hardened criminal for the commission of a serious crime, they might not pass constitutional muster." 71

Questions of application aside, the constitutional approval of cor-

6621 I U.S. 78 (1908); 338 U.S. 25 (1949).

${ }^{67} 430$ U.S. $651,660-63$. This mode of argument is not, however, unique to Ingraham; see Gregg v. Georgia, 428 U.S. I 53 (1976).

${ }^{68} 347$ U.S. 128 (1954).

${ }^{69} 430$ U.S. $651,674-83$.

${ }^{70}$ Ibid., p. 670.

${ }^{71}$ Ibid., pp. 684-85. The Eighth Circuit, with Harry Blackmun writing the opinion, had held in 1968 that beating adult prisoners with a strap was cruel and unusual punishment. It did not rule that all prison corporal punishment was unconstitutional, but the language came very close to doing so (Jackson v. Bishop, 404 F. 2d 57I). 
poral punishment is unacceptable. Arguments in favor of it apply to parents, not to schools. In these cases, the school officials were upheld over parental objections. Several factors distinguish parental corporal punishment from school corporal punishment. First, whatever the merits of parents' imposing it, no state could effectively legislate against it. Second, doctrines of family privacy could put parental discipline beyond state control. The school, however, is an agent of the state, and is controlled by it. Indeed, a third distinguishing factor is the fact that school corporal punishment is public, no matter where it is performed, or whether other children see it. The very nature and purpose of punishment demands that it become known if it is to have the desired deterrent effect. Being flogged is both painful and humiliating, and it is an intrusion into personal body space, which violates fundamental notions of privacy. For all these reasons, it should be considered cruel and unusual.

But Ingraham did not require the Court to say anything of the sort. All it was asked to do was to invalidate severe beatings. And it refused to go even that far, because it could not believe the evidence before it that children need constitutional safeguards; it could not perceive that punishment is punishment, whether for crime or for disobedience; and, above all, it could not quite see children as fully possessing constitutional rights. Adults may not be subjected to arbitrary discipline, but children may; adults may not be beaten, but children may; and children may be abused in a place where they are forced to go. The states have dealt unequally with the young persons under their jurisdiction.

\section{Juvenile Courts and Juvenile Justice}

The common law divided infancy into three seven-year periods for the purpose of determining criminal responsibility. Children under seven were never held responsible for criminal acts; from seven to fourteen, there was a rebuttable presumption of irresponsibility; between fourteen and twenty-one, a rebuttable presumption of responsibility. Now the age of full criminal responsibility is fixed by statute. Suspects below this fixed age are labeled "juveniles" and dealt with in juvenile courts, although some states allow courts to prosecute juveniles as adults in certain circumstances. ${ }^{72}$ Juvenile courts also deal with abandoned or neglected children and with what are known variously as PINS, JINS, and CHINS (persons, juveniles, or children in need of super-

\footnotetext{
${ }^{72}$ But see Breed v. Jones, 42 I U.S. 519 (1975).
} 
vision). Since 1967, the Supreme Court has decided four cases involving juvenile delinquency proceedings. It has ruled that the Constitution grants to juveniles some, but not all, of the protections guaranteed to adults.

That statement implies that before 1967 those courts did not grant these rights. That implication is correct. When the juvenile court movement began early in this century, its advocates were trying to ensure that young people would be helped rather than punished. The goal was "a process designed not as punishment but as salvation." 73 But, as usual, motive did not dictate effect. How far the reality deteriorated from the ideal is shown by the first case, $R e$ Gault. This case was not fifteen-year-old Gerald Gault's first brush with the law. He was already under six months' probation for having been in the company of a boy who had stolen a wallet. Gerald's troubles increased when a neighbor accused him of making obscene telephone calls to her. The maximum adult penalty for this offense was a $\$ 50$ fine and two months' imprisonment, but, after a hearing, the judge committed Gerald to Arizona's Industrial School for six years, until his majority.

The disparity in sentences was bad enough, but it was not the basis for the Supreme Court's reversal. What bothered the Court was that Arizona's juvenile code established proceedings "in which the following basic rights are denied: I) notice of the charges; 2) right to counsel; 3) right to confrontation and cross-examination; 4) privilege against self-incrimination; 5) right to a transcript of the proceedings; and 6) right to appellate review." For the Court, Justice Abe Fortas acknowledged that traditionally a child had no procedural rights and that the original purposes of the juvenile court system had been benign. Nevertheless, his opinion insisted that, by whatever name, what Gerald Gault had endured was a trial and a punishment. "However euphemistic the title, ... an 'industrial school' for juveniles is an institution of confinement in which the child is incarcerated for a greater or lesser time." The Court ruled that all listed rights must be granted juveniles. Only Justice Stewart dissented from the entire ruling. Eight justices agreed that notice and hearing must be provided; seven voted for all Sixth Amendment rights; and six on all Fifth Amendment rights.

The ruling did not affect sentencing, standard of proof, or substantive due-process issues. Long sentences for trivial offenses, or even for such nonoffenses as being in bad company, are still possible. And Stewart's dissent showed that the therapeutic model was still alive and

\footnotetext{
${ }^{73}$ W. v. Family Court, 247 N.E. 2 d 253 (N.Y. Ct.App., 1969). See also Re Gault, 387 U.S. I (1967).
} 
well: “. . a juvenile proceeding's whole purpose and mission is the very opposite of the mission and purpose of a prosecution in a criminal court. The object of the one is correction of a condition. The object of the other is conviction and punishment for a criminal act." ${ }^{74}$

In re Winship came to the Supreme Court with a full exposition of this model in the court below. The New York Court of Appeals had ruled that the required standard of proof in juvenile court trials was "preponderance of evidence" rather than "beyond a reasonable doubt." The judge declared:

The successful juvenile court is concerned primarily with the totality of factors which cause a child to meet difficulty in his life, and only incidentally with the event which brings the child to the court, which may itself play only a small part in that problem.

... A child's best interest is not necessarily, or even probably, promoted if he wins in the particular inquiry which may bring him to the juvenile court.

... If the emphasis is on constitutional rights, something of the essential freedom of method and choice which the sound juvenile court judge ought to have is lost; if range be given to that freedom, rights which the law gives to criminal offenders will not be respected. But the danger is that we may lose the child and his potential for good while giving him his constitutional rights. ${ }^{75}$

In other words, what matters is not whether the child is guilty or innocent, but whether he or she can be "helped." To speak of losing children suggests that we can save them; unfortunately, there is evidence against this proposition. ${ }^{76}$ Again, the child has few rights. Not only can children be held to account by parent and school, but they are subjected to "help" and "salvation" by the state. The Supreme Court reversed, but Stewart again dissented. This time Burger joined him in arguing that what the juvenile court system needed was less, rather than more, formality. ${ }^{77}$

A year later, in 1971, McKeiver v. Pennsylvania held that juvenile court proceedings did not require a jury trial. The Court said that such trials would effectively transform the juvenile court system and "provide an attrition of the juvenile court's assumed ability to function in a unique manner." The Court was unwilling to inflict this transformation on the states. "Perhaps the ultimate disillusionment [i.e., the

${ }^{74} 387$ U.S. I, 10, $27,78-79$.

${ }^{75}$ W. v. Family Court, 247 N.E. 2 d 253-55, 257.

${ }^{76}$ See, e.g., Edwin M. Schur, Radical Non-Intervention: Rethinking the Delinquency Problem (Englewood Cliffs, N.J.: Prentice-Hall, 1973).

${ }^{77} 397$ U.S. 358, 376. 
end of the system] will come some day, but at the moment we are disinclined to give impetus to it." Even Justice Brennan concurred, as long as the proceedings were open to the public. But the dissenters, Black, Douglas, and Marshall, pointed out that every juvenile involved could have been incarcerated for at least five years, and even the plurality opinion admitted that the evidence was weak. "Uniqueness" and "flexibility" sound ominous. ${ }^{78}$

In Breed v. Jones, a unanimous Court held that for a juvenile to be tried as an adult after a juvenile court hearing constituted double jeopardy. ${ }^{79}$ There have not been enough cases, or the right kind of cases, to reveal any marked discontinuities between the Warren and Burger Courts. Certainly the juvenile court system still lives, though its flexibilities have been limited in conformity with some basic requirements of due process. But not all requirements: deference to the therapeutic model and to federalism has restrained the Court, and, as so often happens, such deference has allowed abuses to continue. That may not be the Court's problem, but it is the child's.

This discussion cannot end here. These cases involved children who were charged with offenses that, committed by adults, would constitute crimes, but most juvenile court proceedings involve conduct for which adults cannot be punished by law. ${ }^{80} \mathrm{~A}$ New York law is typical of those in many states. It defines a "person in need of supervision" as "a child who is an habitual truant or is incorrigible, ungovernable, or habitually disobedient and beyond the lawful control of his parent, guardian, or legal custodian." ${ }^{81}$ For this sort of behavior, a juvenile may be taken into custody, put on probation, or otherwise dealt with by court order.

At least three constitutional problems arise here. First, these are behaviors that could not be made criminal without serious violations of due process. Second, the offenses, as defined, are vague and overbroad. A third problem is one of multiple jeopardy: the child may be subject to punishment by family, state, and possibly school for the same act. Such laws mean that a child is not only fully accountable to her parents, and thirty hours a week to the school, but that the state will step in on request and hold her accountable as well.

${ }^{78} 403$ U.S. 528, 547, 555 (Blackmun), 557-79 (Douglas), 536 (Blackmun) (I97I); In re Terry (companion case), 265 A2d 350,355 (Pa. Sup.Ct. 1970). A decision that juveniles were entitled to jury trials would raise one serious problem: since minors do not serve on juries, how could juveniles get juries of their peers? This factor alone might lead to a rethinking of that particular issue.

${ }^{79} 421$ U.S. 519 (1975).

${ }^{80}$ See Howard James, Children in Trouble (New York: David McKay, 1970).

${ }^{81}$ New York Family Court Act, sec. 732. 
Fortas' remark in Gault that a child has no rights is an exaggeration, but only a small one. The child has a limited right to freedom of expression-less than an adult's-and a right to some, but not all, procedural guarantees in school and court. But though the child does have a right to "symbolic speech" as long as no one is disturbed by it, she does not have the right to be informed in clear and explicit terms what conduct will get her in trouble. Though the child has a right to a hearing before suspension, she has no procedural rights before being beaten. Though she has the right to other safeguards before being adjudged delinquent in juvenile court, she has none before being committed to an institution by her parents. It sounds very much as though children are saddled with disabilities that make them a "discrete and insular minority.”

\section{Legal Agism, or Aged Legalism}

The subject of this chapter has not been children's rights alone; it has been age discrimination in general. What, finally, do the old and the young have in common? The cases I have surveyed have generally borne out two of the generalizations we started with: that both older and younger people are presumed to be less competent than that segment of the population between the ages of eighteen and fifty, sixtyfive, or seventy; and that often both groups' interests are, explicitly or implicitly, ranked below those of others. The legal status of both groups reflects these two factors. There are, however, two additional factors that affect the treatment of minors. First, others are presumed to act in their best interests. Older citizens are presumed, absent an official determination to the contrary, to act in their own interests. Since many of the disabilities of the young stem from their presumed incompetence, it is no wonder that this chapter has devoted so much more space to children. Junior citizens are restricted in many ways that senior citizens are not.

The second peculiarity of the situation of children is shown by the fact that, while compulsory retirement cases were handled with the standard equal-protection tests, the children's cases were not. Policies affecting the young are not usually thought to raise issues of equality at all. This is true even though, as Chapter 4 suggested, there is no pressing historical argument against their being so considered. Despite such rhetoric as "the condition of being a boy does not justify a kangaroo court" and "neither students nor teachers shed their constitu- 


\section{Equality under the Constitution}

tional rights to freedom of expression at the schoolhouse gate," 82 the cases do not suggest-indeed, they often reject-any idea that children enjoy any constitutional rights to the same extent that adults do. The cases are not brought as equal-protection cases, and as a result they are not argued with the special terminology of equal protection. Suspect classification does not rear its head, or its two heads, nor do questions of fundamental rights get quite the same weight as they do in cases involving adults. Rights do matter, of course; the two decisions from which I just quoted, Gault and Tinker, are premised on them. But nowhere are these rights equal, so the Court does not compare Tinker with Terminiello, Parham with Donaldson, or Gault and McKeiver with the whole line of due-process cases involving criminal defendants.

What would happen if standard equal-protection doctrine were employed in cases involving children? Certainly, children fall outside the Frontiero suspect-classification rule. Youth, like age, does "frequently bear ... relation to ability to perform or contribute to society." The Rodriguez formulation, however, requires us to ask whether children are "saddled with such disabilities, or subjected to such a history of purposeful unequal treatment, ... as to command extraordinary protection." ${ }^{83}$ However much one wants to add, "But ...," the conclusion is inescapable: children are so saddled, and so subjected. The question then has to be whether they do in fact get "extraordinary protection" from the social agencies that affect them, the family, the school, and the state. But those are the same agencies that impose the disabilities, so it is rather unlikely. We know by now that protection can become a protection racket.

How can my general theory of constitutional equality be applied to age discrimination? All the laws I have been discussing have, at least in part, been premised on presumptions about competence. When older or younger citizens are denied rights or privileges granted others, or burdened with duties that others escape, the discrimination is usually defended by statements that their abilities are limited or diminished. Chapters I through 4 , however, argued that constitutional guarantees of equality depend not on the belief that people are equally capable, but on notions of equal humanity and entitlement, most specifically, entitlement to rights. There is no reason to exclude the old or the young from this entitlement.

Chapter 6 suggested a reformulation of this thesis in terms of con-

${ }^{82}$ Re Gault, 387 U.S. I, 28 (1 967); Tinker v. Des Moines Community School District, 393 U.S. 503, 506 (1969).

${ }^{83} 4$ I I U.S. 677, 686 (I 973 ); 4 I I U.S. I, 28 (1973). 
stitutional doctrine, adapted from Stone's footnote in Carolene Products, Marshall's dissent in Rodriguez, and Brennan's opinion in Bakke. Here I deal with these opinions in what I think is ascending order of clarity and relevance of import. Brennan's opinion adds to a general understanding of classifications, but it is hard to apply here. He insisted that stigmatizing classifications, those that are premised on ideas of inferiority or reinforce prejudice or separation, are invalid. The question then becomes whether the age-based classifications discussed here do either of these things. The answer has to be that some of them do, but I am not sure how far that gets us.

Some of the decisions-Bradley, Parham, and Ingraham come to mind-do seem to be premised on notions of inferiority, of the absence of a right to equal respect and concern. The real question here, however, is not whether we can find court decisions thus premised, but whether the policies are in themselves grounded in such beliefs. In Bradley, the concern for younger Foreign Service officers, suspicious because it excludes those over sixty from equal entitlement, was only one of the justifications for the retirement rule, and one would have to consider the relative weight of it and the other reasons to the rulemakers, not the Court. Because this intent is not always discoverable, it may be impossible to determine whether a given policy stigmatizes in Brennan's sense.

Marshall's contribution to the reformulated doctrine was to emphasize the nature of the classifications involved, the relative importance of the individual claims, and the countervailing force of the state interest. These classifications may or may not stigmatize, but certainly they are troublesome for other reasons. If not immutable, they are involuntary, and they do involve disempowered groups, actually or potentially. The interests involved are all of great importance: a job, in Murgia and Bradley; mobility, in Parham; immunity from arbitrary and even brutal punishment, in Lopez and Ingraham; self-determination, for Walter Polovchak; and, for Chad Green, Joseph Hofbauer, and Phillip Becker, life itself. Tinker, Yoder, and the juvenile court cases all centered around claims that even under traditional rules are classified as fundamental rights; so, of course, would most of the cases mentioned if they involved anyone but children.

These considerations weigh heavily in favor of the claimants. But what about Marshall's third test, the state's interests? How should they be weighted? Since the individual claims involved are of crucial importance, and the basis for discrimination is beyond individual control, and some disempowering and branding seems to be involved, the countervailing claims should be more than merely reasonable. They 


\section{Equality under the Constitution}

would at least have to satisfy the Craig test of substantial relation to an important objective. In Bradley that standard is not met, but in Murgia it may be-so what conclusions should follow?

In many of the children's cases, there is an intervening claim: the interests of the parents, which in Hofbauer, for example, tend to take over in the judges' minds. Newspaper discussions of the Polovchak case show this tendency, too; the conflict becomes state versus parent, not state versus child. Parents do have important rights and duties, and certainly they must have more control over the child than the school or the state does. Most of the time they must be presumed to act in the child's interests. But why does this presumption hold in Parham and not in Ingraham? It is not applied consistently even now, and in such situations as the Polovchak, Hofbauer, and Green cases there is simply too much at stake for it to hold at all. In such cases the children's interests must be considered separately from those of the parents, with the appointment of a separate special counsel for the child, if necessary. ${ }^{84}$

Parham differs from Hofbauer in this respect only because the presumed relationship between parental and child interests is not that the parental interest is superior or "fundamental" but that the two are identical. This assumption is maintained in Parham even in the face of overwhelming evidence to the contrary. The traditional view of the family that is so loved by Burger and Powell seems to crowd out consideration of the facts.

The school cases usually have the child and the parents united against the state, in the persons of school authorities. Consideration of school interests here have tended to be rather mechanical: uncritical acceptance of "the work and discipline of the school" and a willingness to override the school only when any interference was absent or minimal. ${ }^{85}$ Once the strength of the child's claim is recognized, it is hard to uphold the school on the basis of such analysis.

What about the juvenile courts? The decisions, whatever their results, reflect a notion that the purpose of these courts is to help children in trouble, not to punish them. The state's interest here is surely substantial, and not obviously antithetical to the child's. Fair enough, but unfortunately that idea embodies three assumptions: that the state knows when help is needed; that it knows how to help; and that it does help. The cases call all three of these assumptions into question. It was not shown that Gerald Gault needed any rehabilitation; what is evident is that what he got was punishment.

${ }^{84}$ See Farson, “Children's Rights," p. 55.

${ }^{85}$ Tinker v. Des Moines Community School District, 393 U.S. 503, 5 I0. 
But does juvenile court treat children more leniently than the criminal courts treat adult offenders? It is not at all clear that it usually does. Juvenile courts deal with some minors who would not be in trouble at all if they were adults, and they often punish children far more severely than adults could be punished for the same behavior. And, more and more, states are providing that children accused of serious crimes will be tried as adults; in other words, they are foreclosing the possibility of greater leniency, which means that the juvenile courts will be used only when they ensure greater stringency. Obviously, it is up to the states whether they maintain separate court systems at all; it would be difficult to mount an argument that juvenile courts are inevitably violative of constitutional rights. Perhaps children would be better off if they were treated as adults; after all, questions of competence can be considered there. We need more knowledge about whether the juvenile court system ever can be truly benign or helpful. Surely there is no good reason for maintaining it only to the extent to which it is repressive and punitive.

The children's cases that have actually been decided become easy ones when they are judged by the Stone-Marshall equal-protection rule, for the state interest tends to collapse on analysis. But it may not collapse in all cases involving children, and it did not do so in Murgia. I have not argued, nor do I wish to, that all legal distinctions based on age are invalid. As I suggested, compulsory schooling seems to me legitimate, though barely. Likewise, the annual physical examinations required of Massachusetts uniformed state police after age forty, or more frequent licensing tests for older drivers, seem to be a sensible way of enhancing public safety without overburdening older citizens. (A law denying a drivers' license to anyone over a certain age would be another matter.) But would the reformulated rule of interpretation allow us to make these distinctions?

For the maximum-age cases, it does work. The interests are important ones, but in each situation they may be fulfilled through a policy that does not infringe on a fundamental interest. Being required to take a test or a physical exam is not nearly so great a deprivation as being forced to stop working or driving. Furthermore, such a policy is enabling, allowing those who do not fit the prevailing stereotypes about competence to maintain their freedom.

But compulsory schooling presents a harder problem. It deprives children of a considerable amount of freedom. It partakes less of education and more of custody than can be desirable, as these cases show. Finally, it applies to all children, even if they have the skills taught in school or can learn them elsewhere. On the other hand, to the extent 


\section{Equality under the Constitution}

that schooling achieves its purposes-and only to that extent-it fulfills a vital state interest in having an educated citizenry, and it is valuable for the children themselves. The gap between ideals and reality is so wide, however, that acceptance of compulsory schooling must be reluctant and guarded. There should be room for exceptions; perhaps children might be emancipated from education in the same way that they can now be emancipated from parental control. Some age-based distinctions are acceptable, but perhaps none that has so great an impact should be accepted automatically or universally. The problem here is that even the reformulated doctrine cannot deal adequately with this kind of issue. But the principles behind it can help to guide our thinking.

The question of how to discriminate between acceptable and unacceptable restrictions on children is perplexing. Any argument for “children's rights," even so limited an argument as I have made, is easy to trivialize. As one author asks, what happens if "my son, who gets mad at going to bed at 10:30, goes to court and asks for a later bedtime?" ${ }^{86}$ The leading cases do not help us to make these discriminations. But that, I suggest, is precisely the point. The cases are not about bedtimes; they are not even about a boy's right to select a prom date, because the disabilities of minors are so great that they inhibit litigation. Only the most drastic cases get to court at all. And it is very hard to extend the bedtime principle to protect the autonomy of the Beckers, Polovchaks, and Hofbauers.

But if courts begin to uphold children's claims, will such rulings encourage bedtime litigation? Do not families and schools-and courts, too-need to maintain a considerable degree of control over children, and would such rulings not make it harder for them to do so? I am not sure that they would, because they only scratch the surface of children's disabilities. But if they did, I am not sure that would be a bad idea. It is not clear to me why disrespect for a principal, dawdling, or being with a child who steals a wallet should be punishable offenses. The larger point is that it is not clear why the first, most powerful lessons that children-who, after all, will grow up-must learn are obedience and respect for authority. Those are the lessons being taught in these situations. Will those lessons really fit children for life as autonomous adults? Or may they not produce those citizens whom Mark Twain described as having the three precious gifts of "freedom of speech, freedom of religion, and the prudence never to exercise either of them"?

${ }^{86}$ LaMar T. Empey, "Dilemmas in the Search for Utopia," in Empey, ed., Future of Childhood, p. 387. 
I began this chapter by noting the general public acceptance that age-based discriminations have received. The ensuing discussion has shown that case law has mirrored this acceptance. But the cases have also revealed the prevalence of assumptions that claims to equality must rest on capacity and competence; again and again, laws are defended by generalizations about lack of competence. And while these generalizations may be more accurate than some that have been made about other groups, their application to individuals is limited. They correspond better to the antitheory of equality than to the theory. And they are not compatible with a right to equal respect and concern, or with a commitment to individual rights. 